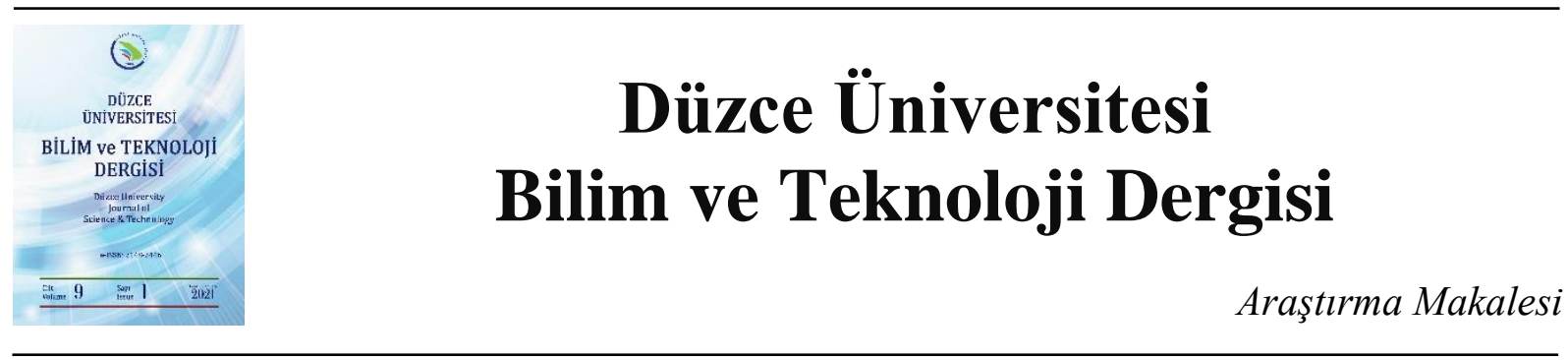

\section{Safranbolu- İncekaya Bölgesi’nde Bir Mimari Stüdyo Deneyimi}

\author{
(iD Ahmet Emre DİNÇER ${ }^{\text {a, }}$, (D) Selda Cansu TEMEL ${ }^{a}$, (ID Sebile Merve ÖZTÜRK ${ }^{\text {a }}$ \\ ${ }^{a}$ Mimarlık Bölümü, Mimarlık Fakültesi, Karabük Üniversitesi, Karabük, TÜRKIYYE \\ * Sorumlu yazarın e-posta adresi: aedincer@karabuk.edu.tr \\ DOI : 10.29130/dubited.774918
}

\begin{abstract}
ÖZET
Çeşitli nedenlerle oldukça hızlı gelişen kentlerde ve onlara eklenen yeni kentsel alanlarda, doğal olarak tasarım sorunları ortaya çıkmaktadır. Safranbolu'nun büyüyen kent çeperinin yakınlarında bulunan arkeolojik, mimarî ve doğal güzellikleriyle turizmin bir parçası olan İncekaya su kemeri ve çevresinde popüler kültüre bağlı oluşan düzensiz yerleşim, bunun örneğidir. Bu sorunun çözümünde çeşitli paydaşları bir araya getiren ve ortak akıl oluşturan kentsel tasarım uygulamalarından faydalanma ihtiyacı vardır. Kentin ve bölgenin gelişiminde önemli katkısı olan, öğrenci yetiştirmenin yanında bilgi üretiminin bir parçası olan üniversite, bu paydaşlardan biridir ve araştırmacı/öğrenci potansiyeline sahiptir. Bu bağlamda, 2019-2020 güz döneminde proje dersinde mimarlık bölümü öğrencileriyle seçilen alanda çalışmalar gerçekleştirilmiştir. Bu çalışma sonunda elde edilen bilgilerin hem öğrenciler açısından eğitime hem de alanla ilgili olarak kente olan katkıları tartışılmıştır.
\end{abstract}

Anahtar Kelimeler: Kentsel Tasarım, Mimarlık Atölyesi, Planlama, Safranbolu-İncekaya. Tasarım Ë̆itimi

\section{An Architectural Studio Experience in Safranbolu-İncekaya Region}

\begin{abstract}
For various reasons, design problems have been naturally emerged in rapidly developing cities and in new urban areas which added to them. As a result of popular culture, the example of these problems has been the irregular settlement around the Incekaya aqueduct and its environment which are is a part of tourism with its archaeological, architectural, and natural beauties, and near Safranbolu's expanding city perimeters. In solving this problem there is a need to take advantage of urban design practices that bring together the various disciplines and create a common mind. One of these disciplines is the university, which contributes significantly to the development of the city and the region and is a part of the knowledge production, with its researcher/student potential. In this context, in the project course in the 2019-20 Fall Semester, the studies concerned with the field have been made with the students of the architectural department of the university. At the end of this study, the contributions of the obtained information to both students' education and to the city, where the study field is evaluated, have been discussed.
\end{abstract}

Keywords: Urban Design, Architectural Studio, Planning, Safranbolu-Incekaya, Design Education 


\section{GIRIS}

Kentsel alanlar; pek çok farklı toplum gruplarından bireyleri barındıran, oluşan eylemler ve tanımlı işlevler aracılığı ile müdahaleye açık olan yerlerdir. Gündelik hayat içerisinde sosyalleşme ve yaşamsal tüm gereksinimler mekânı dahil eden bir devingenlik oluşturmaktadır. Sanayileşmeyle birlikte oluşan bilgi ve tüketim toplumu bu devingenliğin hem öznesi hem nesnesi konumundadır. Edilgen konumda hızı büyümenin parçası ve tüketimin popüler nesnesi ise günümüz modernitesinde mekândır. Bugün boş zaman etkinliği olarak tüketilen mekanlar, kentsel olanın yanı sıra kent çeperinde, kırsalda ve doğal alanda karşılık bulmaktadır. Popüler kültürün etkisi altında gerçekleşen tüketim eylemi ve odak mekânları da sürekli olarak değişmektedir. Ancak tasarım süreci, bu değişime her zaman ayak uyduramamaktadır. Bu durum; düzensiz, uyumsuz ve kitsch üretimle beraber çeşitli tasarım sorunlarını gündeme getirmektedir. Safranbolu'nun büyüyen kent çeperinin yakınlarında bulunan İncekaya su kemeri ve çevresinde popüler kültüre bağlı oluşan düzensiz yerleşim, bunun bir örneğidir.

1976 yılında doğal ve tarihî sit alanı olarak ilan edilen ve 1994 yılında da Dünya Miras Kentleri listesine alınan Safranbolu, ülkemizde turizmin önemli destinasyonları arasındadır. Son yıllarda tarihî merkezi oluşturan eski çarşı bölgesi dışında çevresinde sahip olduğu diğer doğal özellikleriyle de (yeşil dokusu, mağara ve kanyonları vb.) giderek ön plana çıkmaktadır. Bu alanlar arasında İncekaya-Tokatlı kanyonu bölgesi de yer almaktadır. Bu bölge hem jeomorfolojik hem biyolojik çeşitlilik hem de bir parçasını İncekaya Su Kemeri'nin oluşturduğu arkeolojik sit alanı özelliği taşıması bakımından dikkat çekmektedir.

Son yıllarda tarihî kemerin bulunduğu alan ve çevresinde; ziyaretçi potansiyelini artırmak, ziyaretçilerin burada geçirdikleri zaman diliminin süresini uzatmak ve sürekliliğini sağlamak gibi amaçlarla birtakım düzenlemeler (yemek yeme alanları, izleme terasları, satış birimleri, otopark vb.) yapılmaktadır. Madanipour, kentsel mekânı herkesin ulaşabildiği bir yer ve yerli-yabancı insanların az kısıtlamalarla girebildikleri kasaba, şehir ve kırsal mekânların içinde kalan alan olarak tarifler [1]. Safranbolu kent sınırları yakınında ve İncekaya (Gayza) köyü çeperlerinde bulunan bu alandaki yeni oluşumu da bu çerçevede değerlendirmek mümkündür. Christopher Alexander kent tasarımının, adlandırılamayan ama herkesçe kabul edilen belirli bir düzeyde nitelik taşıması gerektiğini belirtir [2]. Bu niteliğin anlaşılmasında, birbirini izleyen sürekli olaylar dizisinin kavranması gereklidir. Olaylar dizisi gerçekleştiği mekânlarla doğal olarak ilişki içindedir. Dolayısıyla kent ve kent parçalarının oluşumlarında da bu dinamik ve birbirleriyle etkileşim halindeki diziler (örüntüler) etkilidir. Bu diziler, kuralları ve niteliği belirler. Örüntüler, morfolojik olarak uygun olduğunda kaos yerine bütünlük oluşur. Ancak, Safranbolu'nun bu bölgesindeki hızlı ve kontrolsüz bir şekilde gelişen yeni kentsel oluşum; ulaşım ve organizasyon eksikliği, süreksizlik, çevreyle uyumsuzluk, estetik problemler gibi birtakım sorunları da beraberinde getirmektedir.

Ülkemizde özellikle de 2000'li yılların sonundan itibaren yaygınlaşan kentsel tasarım kavramı; sosyoekonomik, politik ve idarî, fizikî ve ekolojik yapısı sürekli devinim halindeki yapılı çevrenin, farklı işlevli binaların, bunları besleyen yaya ve trafik hareketlerinin, açık alanların birbirleriyle ilişkilerinin davranış, kültürel tercihler ve ekolojik koşullar çerçevesinde bütüncül tasarlama eylemi olarak tanımlanır [3]. Bir başka tanımda ise; çok boyutlu, çok ölçekli bir yaklaşım olarak, yapı gruplarına görsellik sağlamak, form ve biçim vermek amaçlarıyla yer tanımlama, tanımsız ve köhnemiş bir alana yer duygusu kazandırma eylemi olarak görülür [4]. Yani kent parçalarının, mekân içindeki biçimlenişini, denetleyebildiği araçlar çerçevesinde, önceden tasarlama eylemidir [2]. Ayrıca kentsel tasarım; mimarlığın estetik, tipoloji ve program konularıyla da bağlantı kuran, kentsel planlamanın analitik yöntemlerinden yararlanan disiplinler arası bir yaklaşımdır. Kentsel gelişime yönelik fikir üretme, alt projeleri tanımlama ve olasılıkları sınama, kentle ve yakın çevreyle bütünleşmeyi sağlama, var olan kentsel kimlik profilini destekleme ve yeni mekânsal kimlik profili oluşturma, karar vericilere tavsiyeler sunma kentsel tasarım uygulamalarının amaçları arasındadır [5]. Bu nedenlerle kentsel tasarım çerçevesinde Tokatlı Kanyonu-İncekaya Su Kemeri çevresinin gözden geçirilmesinin, kültürel ve doğal sürdürülebilirlik açısından faydalı olacağı düşünülmektedir. Diker ve arkadaşları tarafından, alanın 
jeomorfolojik özelliklerini ön plana çıkararak, turizm açısından potansiyelinin değerlendirildiği çalışma dışında, seçilen alanla ilgili daha önce yapılmış bir çalışmaya ulaşılamamıştır [6].

Bu çalışma kapsamında, 2019-2020 Akademik Yılı Güz Dönemi Mimarlık Bölümü 4. sınıf öğrencileri tarafindan Tokatlı Kanyonu- İncekaya Su Kemeri çevresinde yapılan tematik kentsel planlama ve mimarî tasarım çalışmaları aktarılmaktadır. Aynı zamanda proje süreçleri tanıtılarak çalışmalar sonucunda ulaşılan bulguların bir değerlendirilmesi yapılmaktadır.

\section{KENTSEL TASARIM VE DEĞERLENDİRME KRITERLERI}

Kentsel tasarım son elli yıldır tanınmış bir faaliyet alanı haline gelmiştir. Hem yapısal hem de işlevsel olarak kaliteli kentsel gelişmeleri tasarlayıp inşa etmek ve bu gelişmeler yoluyla kullanıcının memnuniyetini sağlamak kentsel tasarımın ana hedefleri arasındadır. Kentsel tasarım, kullanıcı beklentilerini gerçekleştiren ve değerlerini temsil eden yapılı çevreyi oluşturma yöntemidir. $\mathrm{Bu}$ sebepledir ki kentsel tasarım, insanların çevreyi kontrol etmek ve uyarlamak için birikmiş teknolojik bilgiyi; sosyal, ekonomik, politik ve manevî gereksinimler için sürdürülebilir yollardan kullanması olarak tanımlanabilir. Aynı zamanda kentsel tasarım, şehirlerin kurulmasında ihtiyaç programının oluşturulmasında insanlar tarafından öğrenilen ve kullanılan bir yöntemdir [7].

Kentsel tasarım, ilk aşamada farklı tasarım ve planlama gibi uzmanlık alanları arasındaki ilişkiyi kurmak ve önemi daha sonra anlaşılmış olan kamusal alanların kalitesi gibi konulara gerektiği gibi yaklaşabilmek amacıyla geliştirilmiştir [8]. Kentsel tasarım çalışmaları çeşitli mekânsal ölçeklerde gerçekleştirilebilir. Böyle bir yaklaşım içinde kentsel tasarım, binalar bütününden kent parçalarına kadar olan ölçekleri kapsamaktadır [2]. Kentsel mekânda çalışan tasarımcının, parçaların bütüne ve bütünün parçalara olan ölçeğinin alt ve üst ölçeklerinin farkında olması gerekmektedir [9]. Tasarımcının görevi, toplumun ihtiyaçlarına en iyi şekilde cevap verecek son ürünü ortaya çıkarmak; bu ürünün hem kültürel olarak kabul edilir hem de sürdürülebilir olmasını sağlamak ve bu hedefler için uygun yöntem ve teknikleri araştırmaktır [7]. Kentsel tasarım alanında ortaya çıkan sorunlar ve zorlukların üstesinden gelmek sadece bir meslek grubu için çok karmaşık olabilir. Bunun yanında kaliteli mekânlar oluşturmak, tasarımcı ya da işverenin ayrıcalığı değildir; kentsel tasarım kentsel alanların günlük yaşamından soyutlanamaz bir süreç olduğundan, bu alanların oluşturulmasına ve işleyişine karışan farklı gruplardan herkesin (merkezi ve yerel yönetimler, yerel topluluklar, iş toplulukları, yatırımcılar, kullanıcılar, gelecek nesiller vb.) başarılı ve sürdürülebilir yerlerin oluşturulmasında oynayacakları bir rol vardır [9]. Dolayısıyla teknik grup düşünüldüğünde mimar, estetik ve imge yaratmada; kent plancısı, sosyal süreci inceleyip değerlendirmede; peyzajcılar, ekolojik koşulların iyileştirilmesinde; mühendisler ise alt yapı sistemlerinin kurulmasında rol almaktadır [3].

Son ürünün ortaya çıkarılma süreci boyunca tasarımcı, oluşturmak istediği birtakım kalite kriterleri belirler. Tasarımın kalitesinin yükselmesi için; tasarımcının belirlediği kriterlerin düzeyini bilinçli olarak yüksek tutması ve alternatiflerin üretilemediği durumlarda bu düzeyin düşmesine kolayca razı olmamas1 gerekir [2]. Tekeli (1993) bir kentsel tasarımının sahip olması gereken kalite kriterlerini veya değerlerini şu şekilde özetler:

Yaşanabilirlik: Kullanıcıların faaliyetlerini gerçekleştirecekleri mekânların en önemli özelliği, sağlık koşullarına uygun olmasıdır.

İşlevine Uygunluk: Mekânların işlevsel uygunluğu; ergonomik açıdan insan vücuduna uygunluğa, kültürel davranış kalıplarına ve kent içindeki uygunluğa kadar farklı birçok düzeye sahiptir. Bu düzeyler konfor ve etkinlik açısından değerlendirilir.

Okunabilirlik: Bir kentsel alanın başarısı insanların o yeri kolayca algılayıp öğrenebilmesine bağlıdır. 
Sağladığı Görsel Doyum: İnsanların yaşadıkları çevreyi estetik açıdan olumlu algılamalarını sağlamak kentsel tasarımın ulaşmak istediği hedefler arasındadır.

Çağrışımsal Algılama Yoluyla Anlam Yüklenmiş Olmak: Bir kentsel tasarıma sembolik algılamalar yoluyla anlam yüklenmesiyle o alana yer niteliği veya kimlik kazandırılabilir. Yüklenen bu anlam kişilere, kültürlere ve zamana göre değişiklik gösterebilir. Sembolik anlam yüklemesi hem mekânsal konjonktüre hem de kültürel tarihe bağlı olacaktır.

Öznel ve Kamu Denetiminde Olan Mekânlar Dengesi: Kentsel tasarım sonuçları toplumun tamamı tarafından tüketilecek olan çoğunlukla kamuya açı mekânların tasarımdır. Bu nedenle kentte yaşayanlar tasarlanan değerlere kolayca ulaşabilmeli ve değerlerin insanlar arasında fırsat eşitliği sunması sağlanmalıdır.

Gerçekleştirilebilirlik: Kentsel tasarımın gerçekçi olması gerekir. Tasarımda önerilerin yaşam biçiminin, bakımlı bir şekilde yaşatılabilmesi tasarımın gerçeklik boyutu içerisinde ele alınmalıdır [2].

Günümüzde endüstrileşme ile başlayan süreçte küreselleşmenin de etkisiyle kentlerimiz, bulunduğu coğrafyanın doğal ve kültürel değerlerinden bağımsız olarak hızla büyümeye başlamıştır. Bu durum özellikle kentlerin genişlemeye müsait çeperlerinde mekân kalitesinden yoksun kentsel alanların ortaya çıkmasına neden olmuştur. Bu kent parçalarının, bulunduğu bölgenin yerel değerlerini koruyacak ve sürekliliğini sağlayacak kentsel tasarım çalışmalarına ihtiyacı olduğu fikri, çalışmanın çıkış noktasını oluşturmaktadır. Çalışmada değerlendirilecek olan alan Esentepe mahallesi Safranbolu İncekaya köyü sınırında yer almaktadır (Şekil 1). Seçilen alan, atölye çalışmaları süresince sözü edilen bağlamda ele alınmış ve tasarımlar yukarıda açıklanmış olan kalite kriterleri çerçevesinde değerlendirilmiştir.
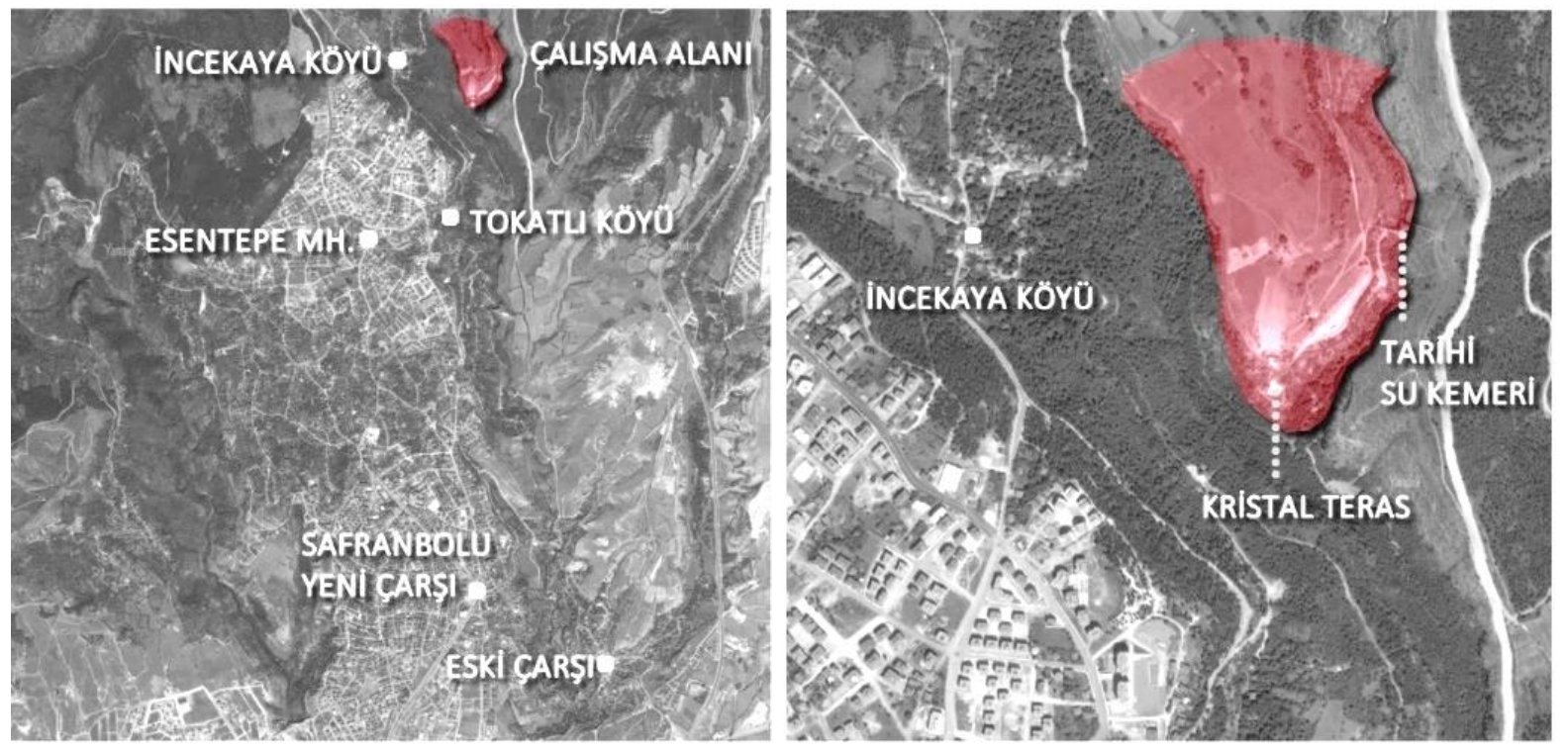

Şekil 1. Çalış̧ma alanı yakın çevresi ve kentle ilişkisi.

\section{MIMARİ TASARIM EĞITIMINDE GENEL YAKLAŞIM}

Mimarlık pratiğinin bir benzetimi olarak, stüdyolar mimarlık okullarının müfredatının ağırlıklı bir bölümünü oluşturur. Stüdyo kültürü bilgiyi yapılandırma, öğretme-öğrenme stratejileri ve öğrenme ortamlarının birbirinin tamamlayıcısı olarak yer aldığı yapının farklı bağlam ve koşullar çerçevesinde yeniden yapılandırılabilme özelliğiyle oluşur ve öğrenmenin gerçekleşme biçimine bir çerçeve sunar [10]. Burada deneyimleme yoluyla bilgiyi sorgulama, keşfetme ve yeniden kurgulama yöntemlerini temel alan bir süreç izlenir. Bu süreçte, birlikte öğrenme ve anlama esastır. Bu bakımdan buradaki 
öğrenme alan bilgisinin, yani özelleşen bilimsel ve teknik bilginin yanı sıra yeni deneyimlerin yeterlik ve kazanımlarının yapılandırılmasını ifade eder [11]. Schön bu süreci meslekî bilginin, stüdyolarda belirli adımlar dizisi oluşturularak her adımda elde edilen sonuçlar çerçevesinde (eylemde yansımayla) geri beslemeli deneyim yoluyla elde edildiği 'yansımalı uygulama' (reflective practicum) olarak tanımlar [12]. Bir başka deyişle stüdyo, öğrencilerin çözmesi için birtakım tasarım problemleri dizisinin belirlendiği yaparak öğrenme sürecidir [13]. Süreç boyunca, birikimin sonucu olarak tasarım bilgisinin şekillendiği holistik bir öğrenme söz konusudur. Bu süreçlerde bilgi ve deneyim edinmeye yönlendirme ve öğrencilerin bireysel düşünceleriyle orijinal düşüncelerin üretilmesi arasında hassas denge gözetilir.

Son yıllarda mimarlık ve kentsel çevre arasındaki etkileşim konusunda artan bilincin bir sonucu olarak, birçok okulun mimarlık lisans ve lisansüstü programlarında kentsel tasarımla ilgili dersler yerini almıştır. Ayrıca araştırmaya dayalı bir süreç olarak stüdyolarda da farklı bağlamlarda tasarım problemleri olarak işlenmektedir. Uygulamada mimarlık, çeşitli paydaşlarla iletişimi gerektiren katılımcı bir süreçtir. Okulların, biçimsel yapısı ve daha çok gayri resmi sosyalleşme yaklaşımları nedeniyle, öğrencileri ihtiyaç duyulan bu katılımcı sürece hazırlamada problemlerle karşılaş1labilmektedir [14]. Günümüzde bilginin giderek arttığ1, toplumun ve sektörün hızlı bir şekilde evrildiği değişen dünya düzenine hazırlama zorluğu söz konusudur. Dolayısıyla öğrenciler, farklı bağlamlar arasında aktarılabilen ve yaşam boyu öğrenmeyi destekleyen bilgi ve deneyimlere ihtiyaç duymaktadır. Öğrencilerin bireysel yeteneğinin yanı sıra toplumsal duyarlılıklarının geliştirilmesi için mimarlık okullarında eğitim, iş birliğine dayalı ve destekleyici olmalıdır. Bu açıdan toplumsal yaşam ve fiziksel çevrenin geniş kapsamlı olarak bir üst ölçekte değerlendirildiği kentsel tasarım stüdyoları, farkındalı̆̆ 1 ve sorumluluk duygusunu arttıran bir ortam sunabilir.

\section{STÜDYO DENEYIMI}

Bu çalışmada, mimarî proje atölyelerinde kentsel tasarım çalışmalarının kavramsal, işlevsel ve ölçekler arası farklarının irdelenmesi amacıyla Safranbolu - İncekaya bölgesi, bir alan çalışması olarak Mimari Proje VII dersinde ele alınmıştır.

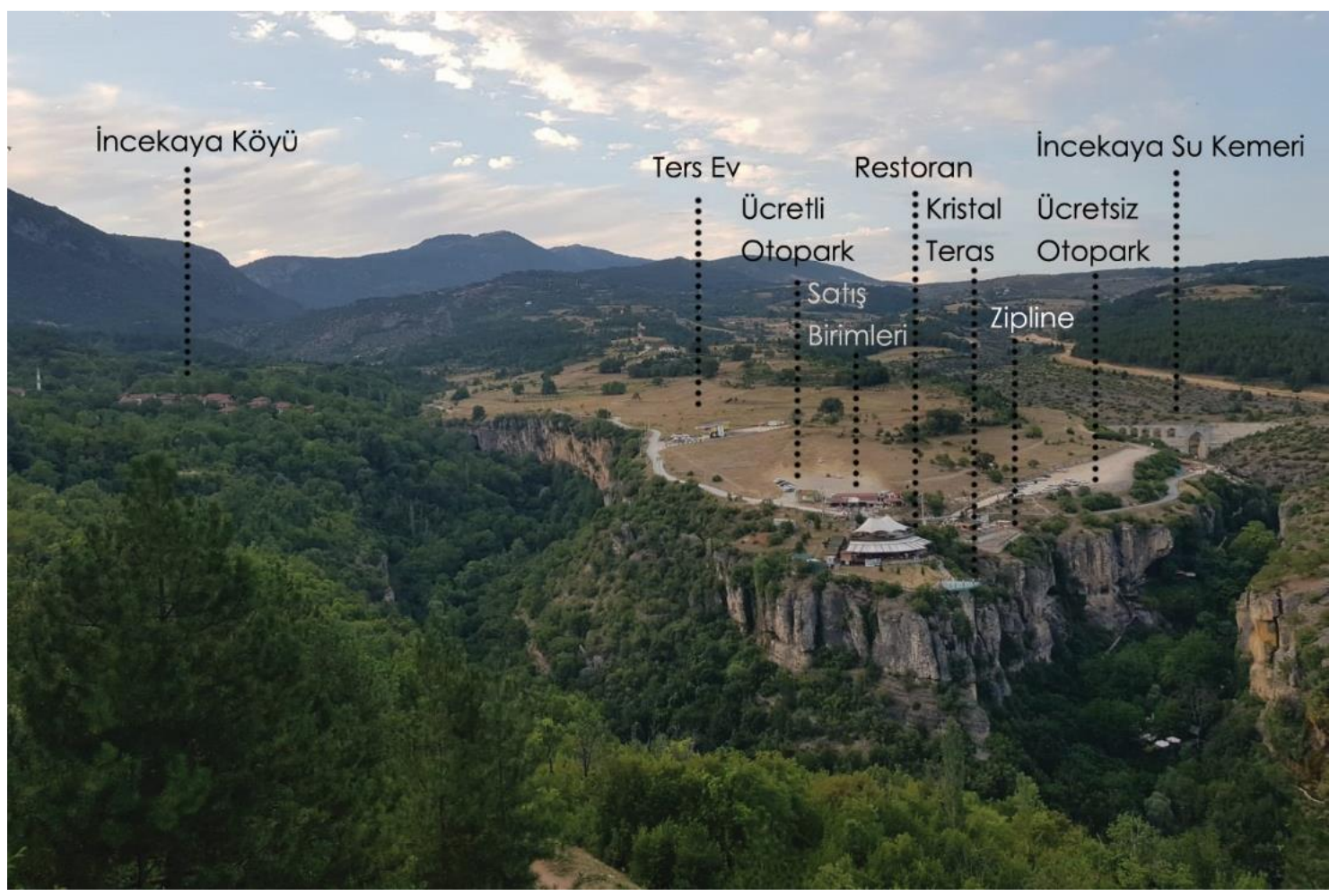

Şekil 2. Çalışma alanının mevcut durumu. 
Safranbolu tarihî dokusu büyük ölçüde korunmuş olan özel bir bölgedir. Proje alanı olarak seçilen İncekaya bölgesi kentsel sit alanlarının sınırında, Safranbolu için yeni bir cazibe merkezi haline gelmektedir. İncekaya Kanyonu ve tarihî su kemeri ile su yolundan oluşan arkeolojik sit alanının da yer aldığ bölgede son yıllarda turizme yönelik müdahaleler gözlenmektedir. Bu değişim süreciyle ilgili olarak, İl Özel İdaresi'nden alınan bilgilere göre, ormanlık bölgede bulunan çalışma alanı Safranbolu Orman İşletme Şefliği tarafindan önce 11.12.2013 tarihinde C tipi mesire alanı ilan edilmiş ve 02.01.2014 tarihinde 29 yıllı̆̆ına özel idareye kiralanmıştır. Daha sonra 25.02.2014 tarihinde B tipi mesire alanına dönüştürülmüştür. Orman ve Su İşleri Bakanlığı Orman Genel Müdürlüğü tarafindan onaylanan kiralanmış alana yönelik gelişim ve yönetim planına göre yürüyüş parkurları, cam teras, kafeterya zipline vb. uygulamalara yer verilmiştir. Buna göre Özel İdare tarafindan 16.11.2012 tarihli kafeterya, 21.05.2019 tarihli zipline inşaatlarına ruhsat düzenlenmiştir. Ayrıca B tipi mesire alanının dışında münferit parsellerde de imar planları gereğince yapı ruhsatları düzenlenmiştir. Bu bağlamda çalışma alanı ve çevresinde İncekaya Muhtarlığına ait yöresel ürünler satış dükkanları, 2019 tarihli ters ev eklenmiş ve (stüdyo sürecinden sonra) 04.09.2020 tarihli dev salıncak ve insan sapanı ruhsatı verilmiştir. Ancak, ağırlıklı olarak turizm amaçlı, bölgedeki canlılığı artırmaya yönelik bu müdahaleler, genellikle popüler kültürün getirisi olan birtakım hizmet mekânları olup tasarım ve işlev olarak bir bütünsellik taşımamaktadır. Oldukça rastlantısal olan bu oluşumlar, artan çeşitli altyapı problemleriyle birlikte, düzensizliğe neden olmaktadır (Şekil 2). Bu bağlamda, bölgede turizmin sürekliliğini ve canlılığını sağlayabilecek, sağlıklı gelişime destek olabilecek ve her türlü ihtiyaca cevap verebilecek, kentsel ve bina ölçeğinde bir proje çalışmasının gerekliliği, tasarım probleminin temel kurgusunu oluşturmuştur.

\section{A. TASARIM SÜRECI}

Proje çalışmasına başlarken, yer ile ilişkinin kurulabilmesi ve arazi verilerinin fiziksel, sosyal, kültürel düzeyde incelenebilmesi için öncelikle proje alanına gezi düzenlenmiştir. Gezinin ardından ön hazırlık süreci başlamıştır. 15 hafta süren ders döneminin ilk 3 haftası proje alanına ve proje konusuna yönelik kuramsal altyapının kurulması, proje içeriğinin arazi analizleri ve örnek çalışmalar ile zenginleştirilmesini içermiş olup; 4 . haftada öğrencilerden ön araştırma ve öncü tasarım yaklaşımlarını jüri ortamında sunarak konunun tartışmaya açılması beklenmiştir. Gerçekleştirilen sunular doğrultusunda, sınıf içerisinde oluşturulan tartışma ortamının ve jüri üyelerinin katkısı ile öğrencilerin kentsel tasarım ölçeğinde alacakları kararlar olgunlaştırılmaya çalışılmıştır. Bu bağlamda, öğrencilerin bireysel tercihlerine bırakılmış olan ihtiyaç programlarının oluşturulması ve toplam kullanım alanının belirlenmesi de jüri esnasında biçimlenmeye başlamıştır. 5. haftadan itibaren öğrencilerden 1/5000, $1 / 1000$ ve 1/500 ölçeklerde kentsel ölçekte aldıkları kararları eskiz ve maket çalışmaları ile destekleyerek geliştirmeleri beklenmiştir. Bu süreçte, tüm ders yürütücüleri ve yardımcıları tarafından verilen kritiklerde; kent-kır ilişkisinin sağlanması, korunması gereken tarihî yapılar ve doğal alanların önerilen proje fikirleriyle içselleştirilmesi, kamusal ve özel alan tanımlarının karşılıklarının aranması yer almıştır. 8. haftada öğrencilere eskiz sınavı yapılmıştır. Sınavın ardından 9. haftada öğrencilerin dönem başından itibaren hazırladıkları tüm çalışmaların istendiği bir jüri süreci gerçekleştirilmiştir. Jüri değerlendirmesi sırasında üst ölçekte alınan kararların, alt ölçek çalışmalara geçilmeden önce yeniden incelenerek, sürecin geri beslemesinin sağlanması amaçlanmıştır. Bu noktadan itibaren 1/5000, 1/1000 ve 1/500 ölçek kararlarına ilave olarak bina ölçeğinde gerçekleştirecekleri 1/200 ölçekli çalışmalara başlanmıştır. Birbirini takip eden son 6 haftada kentsel tasarım ölçeği ve bina ölçeği arasında geri beslemeli bir süreç gerçekleştirilmiş olup; öğrencilerin üst ölçeklerde aldıkları kararların alt ölçeklere gelindiğinde nasıl karşılık bulduğunu ve dönüşümlü olarak alt ölçeklerde bulan karşılıkların üst ölçeklerde birtakım düzenlemeler gerçekleştirilmesi gerekliliğinin kavranması sağlanmaya çalışılmıştır (Şekil 3). Bu doğrultuda atölye süreci boyunca hedeflenen kazanımlar ve kavramlar aşağıda listelenmiştir:

- Tasarım sürecinin bütüncül bir bakış akışı ile ele alınmasını sağlamak,

- Farklı mekânsal ölçeklerde çözüm üretebilme becerilerini geliştirmek,

- Proje alanı olarak seçilen bölgenin ve yakın çevresinin sosyal ve iktisadî gelişimini destekleyebilecek, doğal ve kültürel değerlerine saygılı ve korumacı bir tasarım yaklaşımı kazandırmak, 
- Üst ölçekte alınan kararların daha alt ölçeklerde karşı1ıklarının bulunmasına yönelik düşünme tarzının kazanılmasını sağlamak,

- Kentsel tasarım, şehir hakkı, kamusal alan gibi kavramların bilimsel çerçevede ele alınarak öğrenci algısında yer edinmesi amaçlanmıştır.

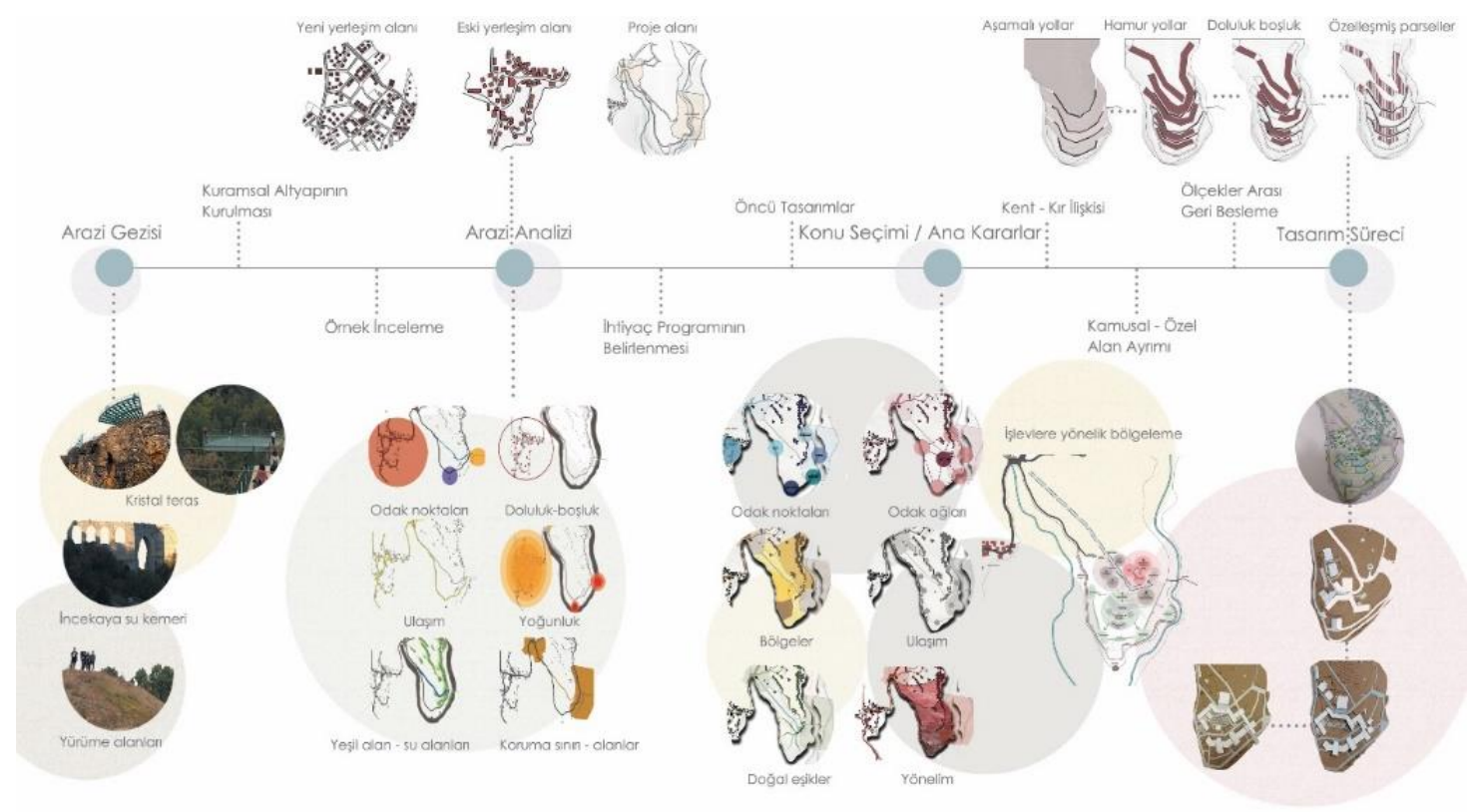

Şekil 3. Proje süreci.

\section{B. ATÖLYE SÜRECINDE ELE ALINAN TEMEL KONULAR VE ÖĞRENCİ ÇALIŞMALARI}

Öğrencilerin bireysel olarak çalıştıkları atölye sürecinde konu seçimleri de bireysel tercihlerine bırakılmıştır. Proje alanına yönelik sorular belirlenmiş (Tablo 1) ve bu problemler ışığında ortaya çıkan fikirler gruplandırıldığında; ekolojik yaşamı desteklemeye yönelik bir turizm modeli, kültürel ve yöresel değerlerin sürdürülebilirliğini amaçlayan sosyo-kültürel merkezler ve müzeler, her yaş kullanıcı grupları için özelleşmiş birbirlerinden farklı eğitim birimleri, atölyeler ile spor ve sağllk tesisleri özelinde bir dağılım olduğu görülmüştür. Bazı öğrenciler ise bu başlıklar altındaki benzer işlevleri bir araya getirerek karma kullanımlı merkez önerilerinde bulunmuşlardır.

Tablo 1. Proje alanı ve yakın çevresinin tanınması amacıyla alana yöneltilen sorular

Safranbolu İncekaya bölgesinin mevcut problemleri nelerdir?

Bölgenin problemlerine yönelik üretilebilecek çözümler nelerdir?

Bölgenin turizm potansiyeli ve memnuniyetin arttırılması için gerekli olan düzenlemeler nelerdir?

Bölgede yer alan mevcut işlevler yeterli midir?

Mevcut köy dokusu ve önerilecek proje nasıl bütünleştirilebilir?

Önerilecek proje ile kültür turizm odaklı bir gelişim, Safranbolu bölgesinde bütüncül olarak nasıl sağlanabilir?

\section{B. 1. Ekolojik Yaşam Faaliyetleri}

Öğrenciler tarafından proje alanı için önerilen tasarım fikirlerine bakıldığında çoğunun ekolojik alt tabanlı olduğu gözlenmiştir. Projelerin genelinde bölgenin doğal güzelliklerinin korunması ve turizmin bu yönde gerçekleştirilecek çalışmalar ile geliştirilerek desteklenmesi gerekliliği söz konusu olmuştur. Bu doğrultuda üretilen projeler kendi içerisinde sürdürülebilir tarım, agro turizm ve doğal yaşam olarak ayrışmaktadır. 


\section{B. 2. Sosyal- Kültürel Faaliyetler}

Atölye çalışmalarında öğrencilerin bir kısmı; toplumun bütününe ya da barındırdığı alt gruplara özgü inanç, gelenekler, kültürel ve sosyal yapıyı ortaya koymayı amaçlayan fikirler geliştirmiş̧tir. Bu amaçla geliştirilen projelerde, Safranbolu'da gerçekleştirilen geleneksel el işleri faaliyetleri ile Safranbolu'nun sahip olduğu doğal ve mimarî dokunun sergilenmesi, korunması ve atölye ortamında deneyimlenmesi ön plana çıkarılmıştır. Bu doğrultuda sanat ve zanaat köyü, unutulmuş el sanatlarını canlandırma merkezi, kültür ve turizm merkezi gibi örnek çalışmalar ortaya konulmuştur. Performans sanatları merkezi ve sahne sanatları merkezi gibi bazı projeler de yenilikçi hedefler ile mevcut kullanım ve dokudan farklı işlevler öngörerek, turizm potansiyelini arttırmayı hedeflemişlerdir.

\section{B. 3. Eğitim- Araştırma Faaliyetleri}

Atölye süreci boyunca, bölgenin kalkınması ve mevcut yapılaşmanın daha düzenli hale getirilmesi konusunda çeşitli tartışmalar gerçekleştirilmiştir. Öğrenci fikirleri bu doğrultuda olgunlaşırken, bölgenin doğal verilerinin korunarak bir toplanma merkezi haline getirilmesinin yararlı olacağı görüşü yaygın bir kanı olarak ortaya çıkmıştır. Bu doğrultuda öğrencilerin bir kısmı, her yaş kullanıcı grupları için özelleşmiş birbirlerinden farklı eğitim merkezleri ve atölyeler önererek, bölgenin cazibe merkezi haline getirilmesini savunmuşlardır. Kimi çalışmalarda da eğitim merkezlerine müze kimliği entegre edilmiştir. Öğrenciler tarafından geliştirilen eğitim merkezi ve müze önerilerine bakıldığında, arazide yer alan su kemeri, su aksı ve botanik dokunun yön gösterici olduğu görülmektedir. Bu amaçla su kültürü ve etnografya müzesi, botanik araştırma merkezi ve müzesi ile flora ve fauna merkezi gibi proje önerileri geliştirilmiştir.

\section{B. 4. Sağlık ve Spor Tesisleri}

Karabük ilinde artan öğrenci sayısı ile genç nüfusa hitap eden etkinliklere duyulan ihtiyaç da artmıştır. Öğrenciler tarafindan ortaya konulan bu görüş 1şığında kimi projelerde spor etkinlikleri ön plana çıkarılmıştır. Bu projelerde hareket kökenli sporlara ilave olarak, her yaş grubuna uygun bir ihtiyaç programı oluşturulmuş olup; bölgenin sağlık, spor ve dinlenme merkezi olması hedeflenmiştir.

\section{B. 5. Karma İşlevli Yaklaşımlar}

Yukarıda yapılan konu sınıflandırmasının dışında herhangi bir konuya ağırlık vermeden işlevlerin eşit derecede ele alındığı projeler ise karma işlevli yaklaşımlar olarak değerlendirilmiştir. Bu gruba dahil olan projelerde farklı işlevler ağırlıklı olarak eğitim ve turizm alanına yönelmiştir. Öğrencilerin seçili bölgede tasarladıkları projelerin, çıkış noktası ve gelişimlerine ait bilgiler Şekil 4 'te özetlenmiştir.

Çalışmalarda; bölgenin tarihi değerlerinin ön plana çıkarılması, kent ve alan arasındaki ulaşım problemlerinin çözülmesi, mevcut doğal dokunun korunması ve değerlendirilmesi ile her yaştan süreli ve/veya sürekli kullanıcı grubuna hitap eden sürdürülebilir işlevler önerilmiştir.

Tasarımlarda çalışma alanına ilişkin yaklaşımlarda öncelikli olarak alanın işlevlere göre dağılımı gerçekleştirilmiştir. Buna göre öğrenciler, öncelikle temalarına uygun olarak mekânları; sesli-sessiz, süreli-sürekli, yoğun-seyrek, özel-yarı kamusal-kamusal gibi kavramlar çerçevesinde bölgelemeler yoluyla ayrıştırmışlardır. İlave olarak analizler sonucunda ortaya çıkarılan alana dair nitelikler ve önerilen yeni işlevler doğrultusunda odak noktaları belirlenmiştir. Başlangıçtan itibaren eş zamanlı olarak, alana yaklaşımın problemleri üzerine yoğunlaşılmış olup; yaya, araç, yeşil doku, tarihî su yolu gibi referanslara göre ulaşım aksları belirlenmiştir. Bu akslar bölgeler arası geçişlerde tanımlı sınırlar oluşturmuştur. Daha sonra yere özgü örüntülerin oluşturulması hedefi ile temalaryyla uyumlu kütle yerleşim kararları alınmıştır (Şekil 5). 


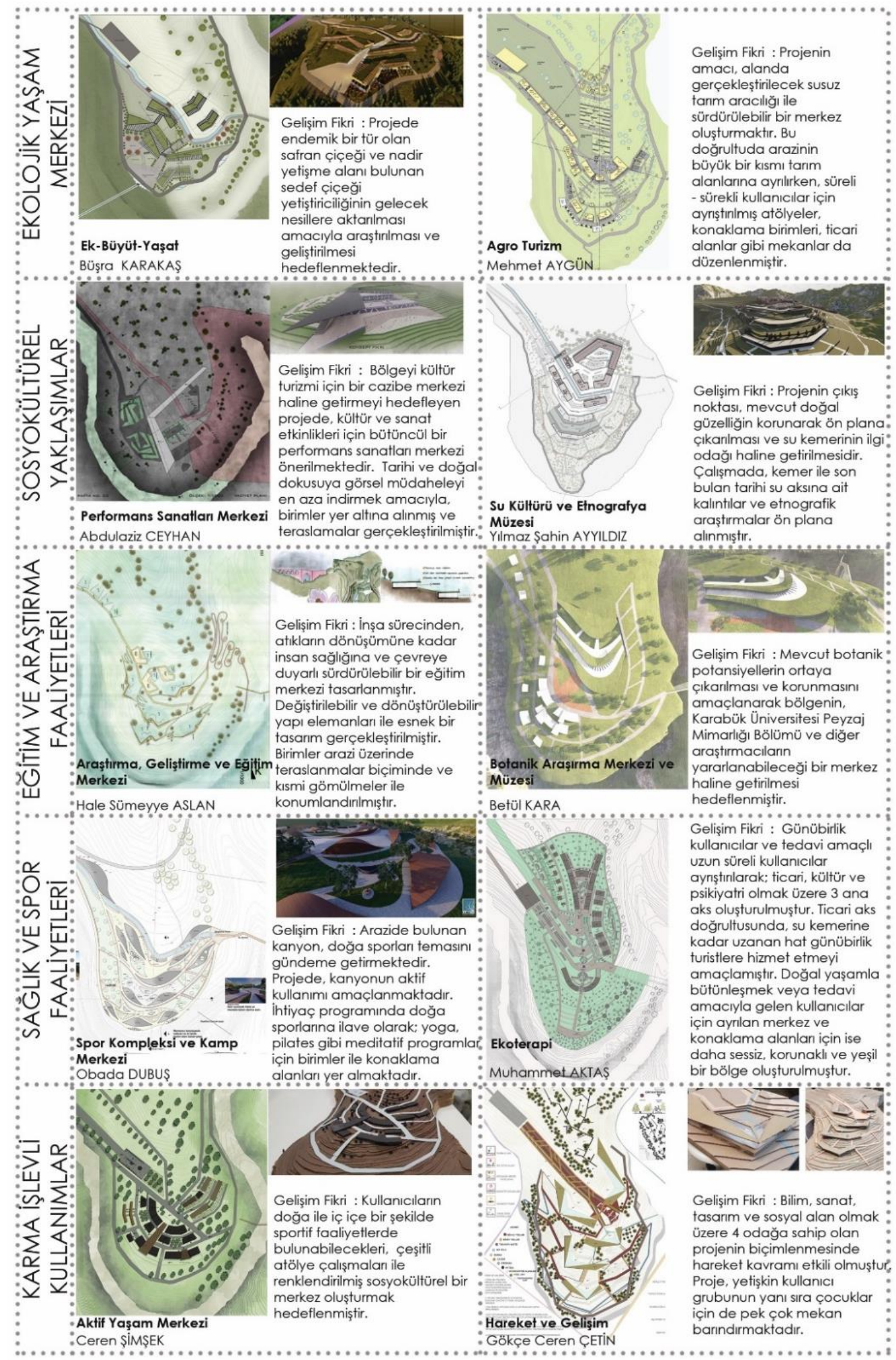

Şekil 4. Öğrenci çalışma temaları ve içerikleri. 


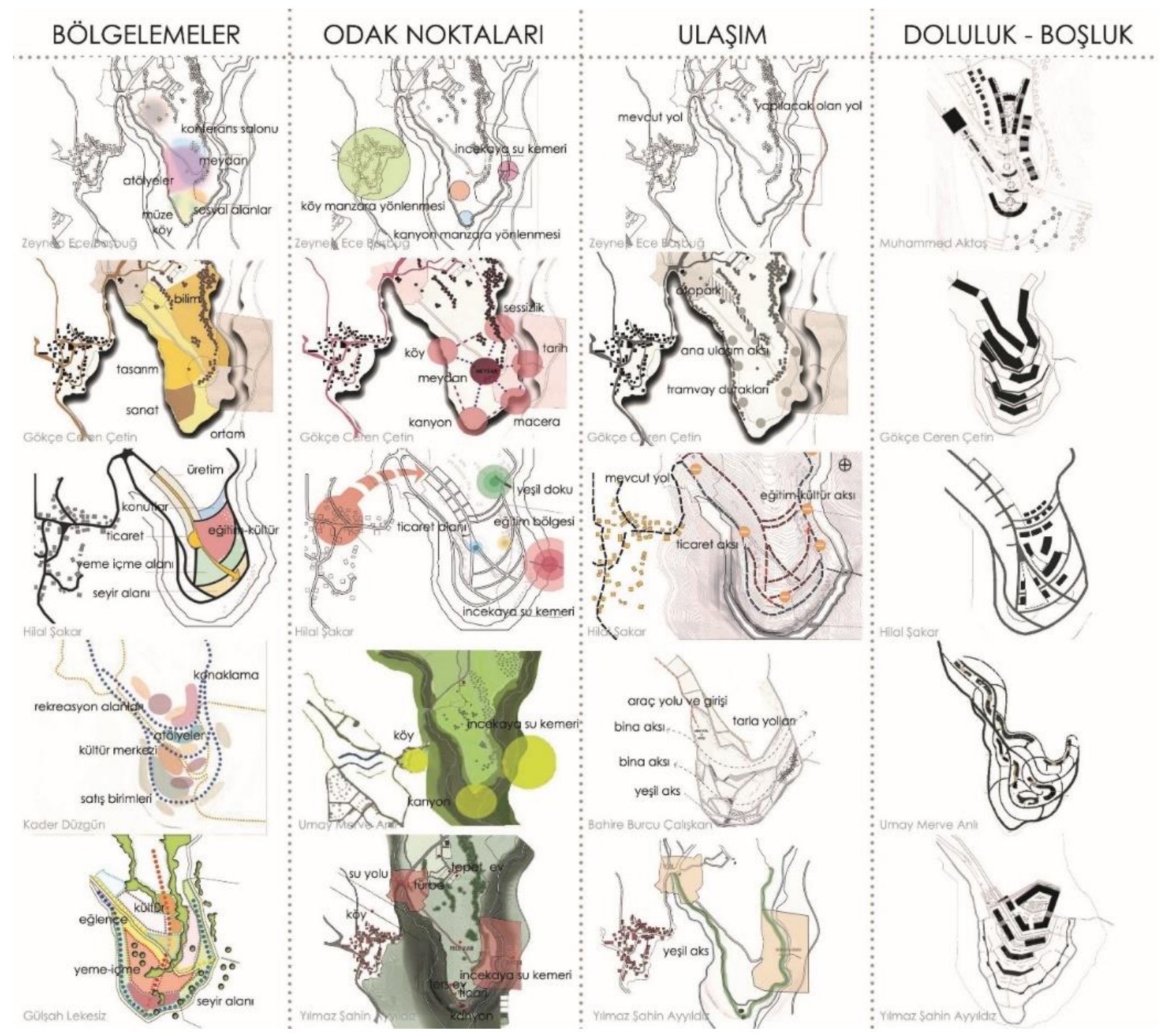

Şekil 5. Projelerde arazi kullanımına yönelik gerçekleştirilen tasarım kararları.

Çalışma alanına ilişkin öğrencilerin önerdikleri temalar çerçevesinde kapalı ve açık mekânlara ilişkin ihtiyaç programını belirlemede aldıkları kararlar ise şu şekilde özetlenebilir (Şekil 6):

Bölgede geçirilen sürenin arttırılmasına yönelik geçici ve kalıcı barınma mekânları önerilirken, çeşitli aktiviteler ile kullanıcının alanda kaliteli zaman geçirmesi hedeflenmiștir. Çevrenin sunduğu olanakların okunabilir ve algılanabilir olmasını sağlamak amacıyla yürüyüş-bisiklet rotaları oluşturulmuş ve seyir terasları tasarlanmıştır. Temaların farklılığına rağmen benzer işlevli mekân önerileri sunulmuştur. Bunun yanında temalara bağlı olarak kullanılan işlevleri karşılamak amacıyla özellikli ve esnek mekân çözümleri önerilmiştir. Çalışmalarda kapalı mekânlar; genellikle eğitim, üretim ve bilgilendirmeye dayalı seminer, atölye, laboratuvar, çok amaçlı salon, kütüphane ve sergi alanları gibi birimleri içermiştir. Sosyal amaçlı kapalı mekânlar genellikle kafe-restoran gibi yeme-içme alanlarını kapsamıştır. Diğer sosyal amaçlı faaliyetlerin daha çok açık mekânlarda karşılanabileceği düşünülmüş, ancak açık alan kullanımında verimli sonuçlar elde edilememiştir. Bu durumun nedeni açık alanlardaki gerçekleştirilecek faaliyetlerde yeterince çeşitlilik oluşturulamamasıdır. 


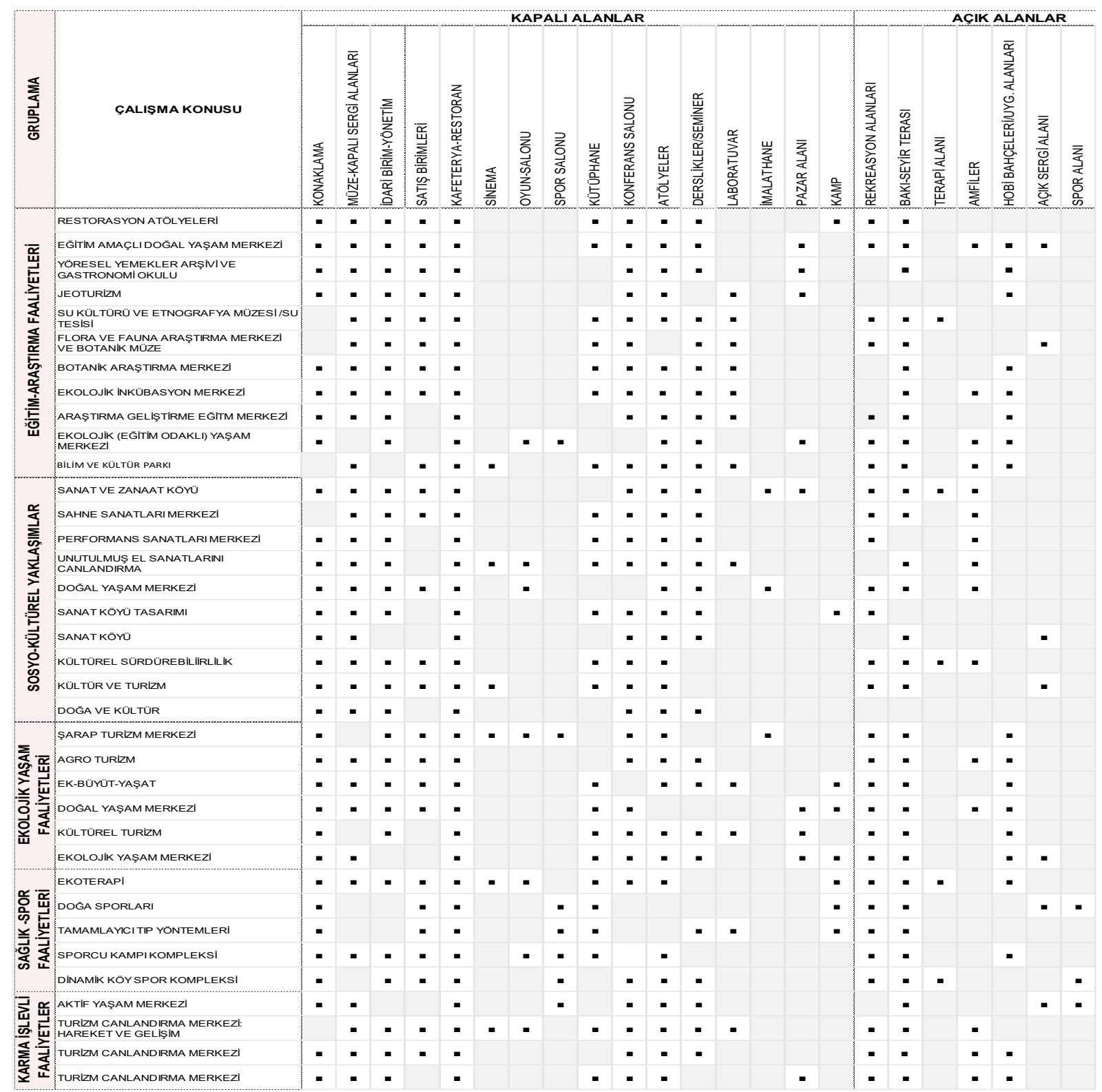

Şekil 6. Proje alanı ve yakın çevresinin tanınması amacıyla alana yöneltilen sorular.

Proje süreci sonucunda; tema ve içeriklerde farklılıklar olmasına karşın, öğrencilerin ortak arayışlar ile bazı noktalarda kesiştikleri gözlenmektedir. Proje alanına yaklaşımda bölgelemeler ile başladıkları analiz çalışmalarında eğim, manzara yönü ve yeşil doku yönlendirici olmuştur. Projelerde öncelikle uzun süreli kullanıcılar ile günübirlik ziyaretçiler için oluşturulan mekânlar, bölgeler ve sınırlar aracılığı ile ayrıştırılmıştır. Kanyon manzarasının sahip olduğu turizm potansiyeli nedeni ile kanyona yakın bölgeler, günübirlik kullanıcılar için düşünülmüştür. Bu doğrultuda ticarî mekânlar ve dinlenme alanları bu bölgelerde yoğunlaşmıştır. Uzun süreli konaklayıcılar için oluşturulan mekânların ise, sessiz ve ayrıştırılmış bir bölgede (genellikle proje alanına giriște kuzeyde kalan bölge) yoğunlaştığı görülmektedir. Tarihî su kemeri ve su aksının da bölgeler arasında doğal bir sınır olarak kullanıldığı gözlenmiştir.

Ulaşım aksları oluşturulurken su kemeri, hemen hemen tüm projelerde bir referans olarak kabul edilmiş ve alanın koruma sınırına yakın bölgelerinde yalnızca yaya erişimine uygun akslar tanımlanmıştır. $\mathrm{Bu}$ doğrultuda alan içerisindeki otoparkın konum ve işlev olarak oluşturduğu problemlere de çözüm üretilmeye çalışıldığı söylenebilir. Çoğu projede otopark, arazinin köyden geliş bölümüne alınmış, alan içerisinde işlevlere göre değişebilen servis ve bisiklet ringleri oluşturulmuştur. Bir başka konu olarak 
ele alabileceğimiz kanyonun varlığı, öğrenciler tarafindan yalnızca manzaradan yararlanma amaçlı düşünülmüştür. Tüm projeler içerisinde sadece üç öğrenci, kanyona iniş noktalarını aktif spor ve dinlenme alanları özelinde belirlemiş ve tasarlamıştır.

\section{STÜDYO ÇALIŞMALARI ÜZERINE TARTIŞMA}

Çalışma sürecinin sonuçlarını süreçte elde edilen kazanımlar ve karşılaşılan zorluklar olmak üzere iki grupta değerlendirmek mümkündür:

Süreçte elde edilen kazanımlar:

Ulaşılabilirlik: İncekaya Kanyonu'na ve Cam teras'a özellikle toplu ziyaretlerde, araçlarla ulaşım sıkıntısı ve araç-yaya düzensizliği mevcuttur. Ayrıca kanyon ve çevresi farklı açılardan farklı manzaraya sahip olmasına rağmen, manzaradan faydalanma yalnızca "Kristal Teras" ile sağlanıyor algısı oluşmaktadır. Öğrenciler, bu problemlere çözüm olarak araç ulaşımını köyün ya da su kemeri aksının sınırlarının belirlediği alanın dışında tutmayı önermişlerdir. Genel olarak köyün de dahil olduğu su yolu aksında bir yayalaştırılmış yol fikrini benimsemişlerdir. Yol mesafeleri düşünülerek, bakı noktalarının belirlenip buralara bisiklet ya da gezi araçlarının konulması önerilerinde bulunmuşlardır. Bu gezi yolu önerisi ile, köyün ve saklı kalan su yolunun başlangıç noktasının da etkin hale gelmesinin sağlanabileceği düşünülmektedir.

İşlevine Uygunluk: Öğrenciler, seçilen bölgenin mevcutta sunduğu koşulları ve çağrıştırdıklarını dikkate alarak, işlev önerilerinde bulunmuşlardır. Öneriler; bölgenin arkeolojik, mimarî niteliklerinin yanı sıra doğal yapısı ve bio-çeşitliliği de dikkate alınarak yapılmış hem turizme yönelik hem de mevcut yaşamın devamlılığına yönelik, üretim, eğitim, sağlık, spor ve kültür gibi özgün, tutarlı ve sürekliliği destekleyebilecek niteliktedir. Önerilerin bazıları, tematik olmakla birlikte psikolojik bir engel oluşturmaması amacıyla genel kullanıcılara hitap eden işlevleri de içermiştir.

Okunabilirlik: Çalışmanın çıkış noktasını oluşturan tanımlanan işlevlerin ve yapay dokuların düzensiz yerleşimi algılanabilirliliği zorlaştırmaktadır. Öğrenciler, çalışma alanında birbirine yakın nitelikteki işlevleri, gereksinimlerine göre bölgelemeler yoluyla gruplamaya çalışmıştır. Farklılaşmalarda yumuşak geçişlere genellikle dikkat etmişlerdir. Üçüncü boyutta oluşturulan doluluk-boşluklarda çevreyle uyum arayışları okunabilirliği arttırmıştır.

Görsel doyum: Arazinin engebeli yapısına uygun yerleşim önerileri geliştirilmiştir. Çevreye müdahale algısını minimum düzeye indirme adına araziye gömülen veya teraslamaları kullanan tasarım örnekleri sergilenmiştir.

Çağrışımsal algılama yoluyla anlam yükleme: Bölgenin sahip olduğu ve farklı kültürler için çekim alanı oluşturan yeşil doku, su öğesinin biçimlendirdiği kanyonlar, karakteristiğini yansıtan köy yaşamı, tarihî nitelikler, çevreleyen kentsel doku ve yeni sahiplerinin gereksinimleri vb. etmenlerin çağrıştırdığ1 kavramlar; tematik yaklaşımlar ve tanımlanan işlevlere genel olarak yansımıştır.

Gerçekleştirilebilirlik: Genel olarak çalışmalar incelendiğinde, öğrencilerin projelerin uygulanabilirliğini ve sürekliliğini sorguladığı ve bu amaca yönelik tasarımlar gerçekleştirdikleri görülmüştür.

Özel ve kamu denetiminde olan mekânlar dengesi: Kristal Teras ve çevresinde oluşan ticarî yerleşimler, kamusal alan özelliğini kısıtlamaktadır. Kristal Terasın ve su kemerinin olduğu alanda öğrenciler tarafından genellikle yürüyüş parkurları önerilerek, bu alan ve çevresinde herkesin kullanabileceği mekânlar tasarlanmıştır.

Seçilen konu bağlamında sınıf mevcudu kalabalık olmasına rağmen, kentsel ölçekteki çalışmalarda bireysel yetenekleri ön plana çıkarmak amacıyla, grup çalışması tercih edilmemiştir. Gerek ders yürütücülerinin eleştirileri gerek seçilen alanın mevcut koşulları ve sahip olduğu potansiyel gerekse 
diğer arkadaş gruplarıyla etkileşimler olsa da bu çalışmada yaptığımız eğilimlere bağlı konu gruplamalarının yanında, çalışmalarda bireysel farklılıklar açık bir şekilde görülmektedir.

Hem kentsel ölçekte hem de bina ölçeğinde çalışma ve bu ölçekler arası geçişler sayesinde, deneyimleme yoluyla, öğrencilerin tasarıma yaklaşımlarında süreci etkileyen dinamikler konusunda kapsamlı düşünme bilinci oluşmuştur.

Karşılaşılan zorluklar:

"Sınırlar; farklılıklar arasında bulunan, bunların komşuluklarıyla ilişkilerini düzenleyen, kimi zaman ise görsel olarak kendini ortaya koymayan psikolojik ayırıcılardır" [15]. Çalışma alanında kanyonlar doğal bir sınır oluşturmakla birlikte arazinin tepe bölümünün bir kısmındaki ağaçlık alan dışında görünürde doğal bir eşik bulunmaması ve çalışma alanının büyüklüğü, sınırların belirlenmesinde öğrencileri zorlamıştır.

Çalışma alanının fiziksel sınırlarını belirleme sorunlarının yanında kentsel ölçekten bina ölçeğine geçiş süreçlerinde kısmen de olsa, zamanın kısıtlı olması sebebiyle uyum sorunları yaşanmıştır.

\section{V.SONUCLAR VE ÖNERILER}

1992 yılında miras kenti olma yolunda bilimsel araştırmaların hızlandırılması hedeflenerek; meslek yüksekokulunun kurulmasıyla başlayan ve 2003 yılında mimarlık bölümünün, 2007 y1lında Karabük iline ait üniversitenin, 2017 yılında da mimarlık fakültesinin kurulmasıyla devam eden süreçte, bu kurumlar bugün yaklaşık 50.000 öğrencisiyle hem Karabük hem de Safranbolu için bölgenin gelişiminde itici güç olmuştur. Ancak yine de kentin gelişiminde yerel yöneticilerle üniversite iş birliğinin daha da arttırılması, özgün fikirlerin gelişiminde meslekî eğitim alan öğrenci potansiyelinin de değerlendirilmesi, böylelikle problemlerin çözümlerinde alternatiflerin oluşturulmasının bir ihtiyaç olduğu düşünülmektedir. Bunun için akademisyenlerin/ders yürütücülerinin de daha etkin rol alması ve bölgenin dinamiklerini izleyerek ders planlamalarını bu yönde yapmaları gerekli görülmektedir. $\mathrm{Bu}$ katılımcı yaklaşımın, mezun sayılarının giderek arttığ 1 ve koşulların zorlaştığ1 mesleki ortamda öğrenciler için de iyi bir motivasyon aracı olacağı ve eğitimde niteliği arttıracağı düşünülmektedir.

Sürecin başında araziye yönelik gerçekleştirilen araştırmalarda alanın köy ve yakın çevresi ile sosyal ve fiziksel bağlantı kopuklukları olduğu belirlenmiştir. Dönem boyunca öğrenciler, mevcut kopukluğu gidermeye yönelik hedefler ile alana yaklaşmışlardır. Proje dersi sonucunda gerçekleştirilen çalışmalar başarılı bulunmakla beraber, ileride yapılması planlanan çalışmalarda sınırların genişletilerek; kent, köy ve kırsal arasındaki ilişkinin bütüncül bir bakış açısı ile yeterli zaman dilimi içerisinde, konunun uzmanları tarafından ele alınmasının gerekli olduğu düşünülmektedir.

Sahip olduğumuz değerlerin korunmasından ziyade hızlı bir şekilde tüketildiği günübirlik hızlı çözümler yerine, korumanın yanında değişen yaşam koşullarına dair ihtiyaçların karşılandığı ve geleceğe dönük olası sonuçlarının irdelendiği belirli zaman dilimine yayılan geniş kapsamlı bir çerçevede değerlendirme yollarının aranması bir zorunluluktur. Bu çalışmada vurgulanmaya çalışıldığı gibi okulların bir alt bilgi üretim aracı olarak kullanıldığı ve bu bilginin üst karar vericilerle koordinasyon ve iş birliği ile değerlendirildiği bir sistemin kurulmasına ihtiyaç vardır. Çalışma sırasında, çalışma alanı ve çevresinin gözlemledikçe ve deneyimledikçe kullanıcılara sağladığı olanakların oldukça fazla olduğu tespit edilmiştir. Ama bunların tanımladığımız gibi; bilinçli, sistemli ve özenli bir planlama ile yapılması sayesinde sürdürülebilir bir nitelik kazanacağını belirtmek gerekir.

Son olarak sürdürebilirlik kavramı bağlamında çeşitli sertifika programları yer almaktadır. Kentsel ölçekte kullanılan "Leed ND” sertifikası bunlardan biridir. Bu sertifika programı, bu çalışmada çokça bahsi geçen, akıllı konum ve bağlantı, çevre düzeni ve tasarımı, komşuluk örüntüsü ve tasarımı, yenileme, bölgesel öncelik gibi başlıkları kapsamaktadır [16]. Bu bağlamda UNESCO tarafından 
koruma altına alınan Safranbolu çevresinin de bu sertifika programı çerçevesinde ele alınması kentin marka değerine olumlu yönde katkı sağlayarak bir motivasyon kaynağı olacağını söylemek mümkündür.

TEȘEKKÜR: Tasarım stüdyosunu çalışma alanı ile ilgili teknik ve resmi bilgilerle destekleyen Karabük İl Özel İdaresi İmar ve Kentsel İyileştirme Müdürlüğü'ne, süreçte değerli katkılarını esirgemeyen Mimar Elif Hacıalioğlu'na ve tüm öğrencilerimize teşekkür ederiz.

\section{KAYNAKLAR}

[1] M. İnceoğlu ve A. Aytuğ, "Kentsel Mekânda Kalite Kavramı," Megaron Dergisi, c. 4, s. 3, ss. 131-146, 2009.

[2] İ. Tekeli, "Bir Kentsel Tasarım Kuramının Geliştirilmesi Üzerine Düşünceler," Ege Mimarlık Dergisi, c. 1, s. 2, 1993.

[3] A. Karaman, "Kentsel Tasarım: Kuramlar, İlkeler ve Roller," Mimar.ist Mimarlık Kültürü Dergisi, s. 29, 2008.

[4] M. G. Çöteli, "Görsel Planlama ve Pitoresk'i Yeniden Kurmak: Kentsel Tasarım Stüdyo Eğitiminde Kentsel Problemlere Yaklaşım," Sanat ve Tasarım Dergisi, s. 19, ss. 33-53, 2017.

[5] A. Vardar, "Nazım plandan nesir projelere kentsel tasarım," Planlama Dergisi, s. 3, ss. 20-32, 2005.

[6] C. Moughtin, R. Cuesta, C. Sarris, ve P. Signoretta, Urban design: Method and techniques. London: Routledge. 2003.

[7] O. Diker, T. Deniz ve A. Çetinkaya, "Jeoturizm Kapsamında Safranbolu'da Coğrafi Kaynakların Değerlendirilmesi ve Safranbolu Jeoturizm Potansiyelinin Belirlenmesi," Karabük Üniversitesi Sosyal Bilimler Enstitüsü Dergisi, c. 6, s. 2, ss. 334-348, 2016.

[8] Ş. Önal Hoşkara, "Kentsel Tasarım Kuramı, Dün, Bugün, Yarın ve İstanbul Yansımaları," Mimar. ist Mimarlı Kültürü Dergisi, s. 29, 2008.

[9] M. Carmona, T. Heath, S. Tiesdell ve T. Oc, Public places, urban spaces: the dimensions of urban design. London: Routledge, 2010.

[10] S. Aydınlı, “Tasarım Eğitiminde Yapılandırıcı Paradigma: “Öğrenmeyi Öğrenme,” Tasarım+ kuram dergisi, c. 11, s. 20, ss. 1-18, 2015.

[11] N. Paker-Kahvecioğlu, "Architectural design studio organization and creativity," ITU AZ Journal, c. 4, s. 2, 2007.

[12] D. A. Schön, The design studio: An exploration of its traditions and potentials. London: International Specialized Book Service Incorporated, 1985.

[13] B. Lawson, How designers think: The design process demystified, London: Routledge, 2006.

[14] D. Nicol, ve S. Pilling, "Architectural education and the profession: preparing for the future," in Changing Architectural Education: Towards a New Professionalism, D. Nicol, \& S. Pilling Eds. London, New York: Spon Press, 2000, ss. 1-21. 
[15] A. Şentürer, N. Paker, Ö. Berber ve A. Şenel, Taarla: İstanbul İçin Öngörüler. İstanbul: İTÜ Vakfı Yayınları, 2014.

[16] S. Sipahi ve C. Tavşan, "Kentsel Dönüşümde Sürdürülebilirlik: Trabzon Çömlekçi Mahallesi Örneği," Online Journal of Art and Design, c. 7, s. 4, 2019. 